\title{
A METHOD TO SET-UP CALIBRATION CURVE FOR INSTRUMENTED SPHERE IS100 TO CONTROL MECHANICAL DAMAGE DURING POST-HARVESTING AND HANDLING OF ORANGES
}

\author{
Giovanni Carlo Di Renzo, Giuseppe Altieri, Francesco Genovese, Carmen D'Antonio
}

\section{Introduction}

The mechanical and physical quality of fruits depends on several factors: species, variety, pre-harvest (climate, farming techniques) and post-harvest (handling, cooling, storage and distribution) practices [Beni 2001]. Furthermore fruit resistance to physical damage depends on ripening status at the harvest, that is related with the mechanical resistance of the fruits [Alferez 2003; Henriod 2006].

The recent market changes and the increased consumer awareness caused many changes in the properties of the selected varieties, preferring high productivity, short cycle and high pathogens resistance.

Nevertheless, postharvest management is responsible for fruits damages, causing quality deterioration and commercial losses, so it could be necessary to evaluate fruits adaptability to several postharvest operations, comprising conveyance, cooling, packing and storage [Garcia Ramos 2003; Henriod 2006; Zerbini 2003].

During storage, the fruit metabolism (both respiration and transpiration) causes a mass loss (water and sugars), depending on the physiologic properties (climacteric or non climacteric). For example, citrus fruits (non climacteric species) decay slowly if optimal storage conditions (temperature, humidity, volatiles and pathogens control) are applied.

Then, higher is the ripening stage and lower is the mechanical resistance, further serious fruits damages arise from application of unsuitable handling practices during the post-harvest management [Cerruto 2004; Crisosto 2001; Mohammed 2000; Mohsenin 1986; Opara 2007].

Even though many Authors evaluated the efficacy of individual postharvest operations on the fruits qual-

Paper received 17.02.2009; accepted 04.11.2009

Di Renzo G.C., Altieri G., Genovese F., D’Antonio C., Dipartimento Tecnico Economico - Università della Basilicata, Viale dell' Ateneo Lucano, 10 - 85100 Potenza (Italy). Email: giuseppe.altieri@ unibas.it. ity, comparing several ripening stages and varieties [Bollen 2001; Bollen 1990; Garcia 1995; Laykin 1999; McGlone 1997] it is important to assess the effects of combined postharvest operations on the fruit quality. In fact during postharvest processing, fruits undergone several operations (washing, waxing, sorting, packing) that could cause mechanical damages, due to the collisions, among the fruits, with the equipment stuff and with the package material [Gan Mor 2000].

Mechanical damage has two consequences: bruise appearance and peel wounds, which reduce the commercial value of the fruit [Baritelle 2001; Mohsenin 1986]. Particularly for orange fruits, mechanical damage can permanently deform the albedo vegetal tissue, involving the breaking of the oleiferous cells, and consequently a decreasing shelf-life.

In fact, a damaged fruit is subject to a wide rot development which extends to the nearby fruits [Brown 2000; Skaria 2003].

The fruit impact evaluation requires the availability of an object similar to the fruit, by volume and weight, which could both measure and record the collision frequency and intensity while it goes across the processing line, and doesn't interfere with it [Bajema 1998a; Bajema 1998b; Ragni 1998].

A response for this requirement is represented by the instrumented sphere (IS100 device), also known as "pseudofruit", which can be placed on the processing line to measure and record all the received collisions [Blandini 2007; Blandini 2005; Blandini 2003; Delwiche 1996; Di Renzo 1997; Miller 1991; Tennes 1988; Zapp 1990].

In this article Authors propose a calibration curve for the evaluation of mechanical damage threshold for oranges, then the IS100 was used on several calibration lines both to evaluate the damage points and to reduce the mechanical damage on the handled fruits.

\section{Materials and methods}

An instrumented sphere IS100 (see fig. 1), supplied with both a measuring and recording system, 
manufactured by Techmark Inc., Lansing, MI (131.06 grams of mass and $63 \mathrm{~mm}$ diameter) was used to evaluate the produced impacts.

To obtain the critical damage curve as a threshold curve that allows to assert a probabilistic damage to the fruit (e.g. to the 10\% significance level), both several falling heights and materials were tested.

The IS100 device fell respectively onto an hard surface (steel) (heights from 1 to 15 with increment of $1 \mathrm{~cm}, 20$ and $25 \mathrm{~cm}$ ), a neoprene surface ( $7 \mathrm{~mm}$ thickness, $36.9 \mathrm{~kg} / \mathrm{m}^{3}$ density, heights from 1 to 30 with increment of $1 \mathrm{~cm}$, and $35 \mathrm{~cm}$ ), a foam rubber surface ( $5 \mathrm{~cm}$ thickness, $26.2 \mathrm{~kg} / \mathrm{m}^{3}$ density, heights from 1 to 25 with increment of $1 \mathrm{~cm}, 30,35,40$ and $45 \mathrm{~cm}$ ), and a layer of citrus fruits (heights from 1 to 25 with increment of $1 \mathrm{~cm}, 30$ and $35 \mathrm{~cm}$ ), to simulate the collisions among the fruits.

The fruits fell respectively (heights of 15, 25 and 35 $\mathrm{cm}$ ) onto an hard surface (steel), a neoprene surface (7 $\mathrm{mm}$ thickness, $36.9 \mathrm{~kg} / \mathrm{m}^{3}$ density), and a layer of citrus fruits, to simulate the collisions among the fruits.

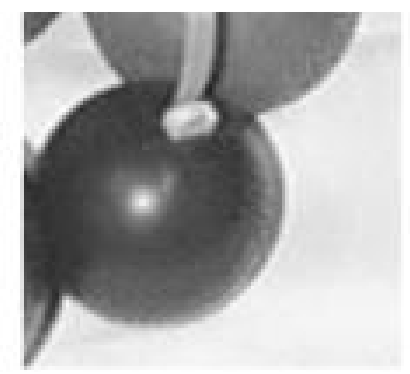

Fig. 1 - The instrumented sphere IS100.

To reduce or eliminate the error due to the throw of the fruit from the operator, a specific device was built up (see fig.2)

Orange fruits (Navelina cv.), provided from the Prometas Cooperative Association (Policoro, Basilicata, Italy), were carried to the laboratory, sorted and divided into groups. The average characteristic property values of the oranges used in the trials are reported in table 1 .

\begin{tabular}{cccc}
\hline $\begin{array}{c}\text { Average } \\
\text { diameter } \\
(\mathrm{mm})\end{array}$ & $\begin{array}{c}\text { Weight } \\
(\mathrm{g})\end{array}$ & $\begin{array}{c}\text { Firmness } \\
(12 \mathrm{~mm} \text { diameter probe }) \\
(\mathrm{kg})\end{array}$ & $\begin{array}{c}\text { Sugar } \\
\text { content } \\
\left({ }^{\circ} \mathrm{Brix}\right)\end{array}$ \\
\hline $\begin{array}{c}85.58 \\
(3.76)\end{array}$ & $\begin{array}{c}281.18 \\
(32.29)\end{array}$ & 3.05 & 9.30 \\
& $(0.36)$ & $(0.27)$ \\
\hline
\end{tabular}

TABLE 1 - Average characteristic property values of the oranges used in the trials, with standard deviation in parenthesis.

For the falling trials of fruits altogether 10 orange lots were collected, and each lot was divided into 3 groups of 5 fruits, with the aim to accomplish the trials for 3 falling height and 3 kinds of surface (steel, neoprene and fruits).

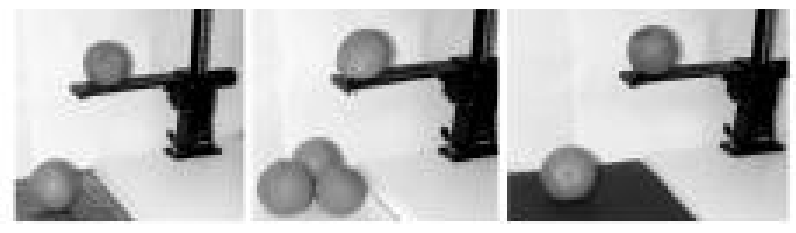

Fig. 2 - Device used to evaluate the fruit falling damage from various heights onto various materials.

Fruit firmness was evaluated by destructive penetrometer test, with a $12 \mathrm{~mm}$ diameter probe; maturity stage of the citrus fruits was evaluated using a refractometer on the fruit juice.

Each fruit was weighted and number signed, then the fruits were precooled ( 6 hours at $10^{\circ} \mathrm{C}$ ) and stored in a cold room $\left(8^{\circ} \mathrm{C}, 94 \% \mathrm{RH}, 32\right.$ days).

After 13, 21 and 32 days of storage, weight loss, fruit firmness and sugar content were evaluated on each group of fruits. The values of fruit firmness and sugar content have not been reported in the results section because they didn't shown any correlation neither with the days of storage neither with the falling heights.

The weight loss increase with respect to the control was used as an index of the fruit damage.

At last, fruit impact damage was evaluated, placing the instrumented sphere (IS100 device) on the processing line for several kinds of sorting line

- Mechanical sorting;

- Compact line and mechanical sorting;

- Weighing sorting;

- Optical-volumetric sorting.

Fruit processing line was composed of: discharging fruits in bins, washing, brushing, waxing, drying, sorting, calibrating and packaging.

The instrumented sphere (IS100 device) was placed at the beginning of the processing line, among the fruits in the bins.

\section{Results from fall tests of instrumented sphere by various heights onto various kinds of materials}

In figure 3 are reported the recorded impact versus acceleration values for IS100 device falls onto the several tested materials.

Each curve shows, for a specific material, the calculated impact velocity (as $\sqrt{2 \mathrm{gh}}$, where "g" is the gravity acceleration and " $h$ " is the falling height) and the "velocity change", obtained as the integral of the acceleration curve (like a "bell") before and after the acceleration peak detected: this is done by the IS100 internal software.

The measured values show a direct correlation between the calculated velocity and the acceleration, except for the impact of IS100 device on fruit, due to the difficulty to carefully hit the target fruit and further to inelastic behavior of fruits at the high impact velocities. 

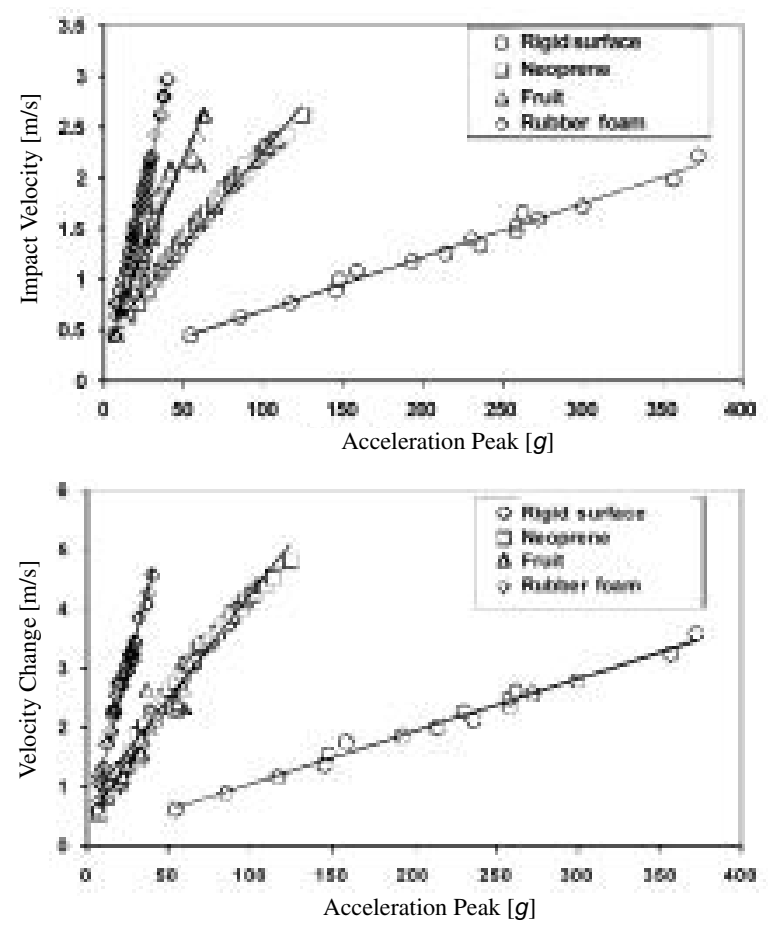

(a)

Fig. 3 - IS100 data acquired during the falling damage tests onto various kinds of materials: impact velocity vs. acceleration peak (a); velocity change vs. acceleration peak (b).

\section{Correlation between impacts of instrumented sphere and citrus fruits damages}

A previous analysis of the damage critical points, due to the fruits impact on the several tested stuffs (rigid surface, neoprene, fruits) was evaluated, before using the IS100 on the processing line.

With this aim a variance analysis (Two-way ANOVA) [MATLAB Statistic Toolbox Reference 2001; Snedecor 1989] for the weight loss was performed, with respect to the falling height and the storage period; the analysis shows that there is a significant variation at 5\% significance level; moreover at $1 \%$ significance level a significant variation was shown only for falls onto the rigid surface.

The data (see tab. 2, tab. 3 and tab. 4) show that, as expected, the weight loss increased as both the impact energy and the impact surface rigidity increased.

Furthermore was performed a post-hoc analysis of multiple comparison test of averages in order to evaluate both the significance level between cold storage days for each of the falling heights and between falling heights for each of the cold storage days, assuming as null hypothesis the equal averages of weight loss percent.

\begin{tabular}{ccccc}
\hline Days of cold storage & \multicolumn{4}{c}{ Falling height $(\mathrm{cm})$} \\
\hline & 0 (control) & 15 & 25 & 35 \\
13 & $-2.48 \%{ }^{\mathrm{aA}}$ & $-2.71 \%{ }^{\mathrm{b} \mathrm{A}}$ & $-2.89 \%{ }^{\mathrm{c} \mathrm{A}}$ & $-3.03 \%{ }^{\mathrm{d} \mathrm{A}}$ \\
21 & $-3.04 \%{ }^{\mathrm{a} \mathrm{B}}$ & $-3.37 \%{ }^{\mathrm{aB}}$ & $-3.36 \%{ }^{\mathrm{a} \mathrm{B}}$ & $-3.26 \%{ }^{\mathrm{a} \mathrm{B}}$ \\
32 & $-4.35 \%{ }^{\mathrm{aC}}$ & $-4.39 \%{ }^{\mathrm{aC}}$ & $-4.80 \%{ }^{\mathrm{aC}}$ & $-4.80 \%{ }^{\mathrm{a} \mathrm{B}}$ \\
\hline
\end{tabular}

TABLE 2 - Data of the weight loss of fruits fall on fruits (equal lower case letters means no significance at $10 \%$ level along the rows, equal upper case letters means no significance at $10 \%$ level along the columns).

\begin{tabular}{|c|c|c|c|c|}
\hline \multirow[t]{2}{*}{ Days of cold storage } & \multicolumn{4}{|c|}{ Falling height $(\mathrm{cm})$} \\
\hline & 0 (control) & 15 & 25 & 35 \\
\hline 13 & $-2.48 \%$ a A & $-2.77 \%{ }^{\mathrm{bA}}$ & $-2.99 \%{ }^{\mathrm{cA}}$ & $-3.23 \% \mathrm{~d} \mathrm{~A}^{\mathrm{d}}$ \\
\hline 21 & $-3.04 \%$ a B & $-3.41 \%$ b B & $-3.39 \%$ b B & $-3.19 \%$ ab A \\
\hline 32 & $-4.35 \%$ a C & $-4.65 \%{ }^{\text {a C }}$ & $-4.59 \%$ a C & $-4.71 \%$ a B \\
\hline
\end{tabular}

TABLE 3 - Data of the weight loss of fruits fall on neoprene (equal lower case letters means no significance at 10\% level along the rows, equal upper case letters means no significance at $10 \%$ level along the columns).

\begin{tabular}{ccccc}
\hline Days of cold storage & \multicolumn{4}{c}{ Falling height $(\mathrm{cm})$} \\
\hline & 0 (control) & 15 & 25 & 35 \\
13 & $-2.48 \%{ }^{\mathrm{aA}}$ & $-3.11 \%{ }^{\mathrm{b} \mathrm{A}}$ & $-3.48 \%{ }^{\mathrm{c} \mathrm{A}}$ & $-3.79 \%{ }^{\mathrm{dA}}$ \\
21 & $-3.04 \%{ }^{\text {a B }}$ & $-3.37 \%{ }^{\text {a A }}$ & $-3.29 \%^{\text {a A }}$ & $-3.47 \%{ }^{\text {a A }}$ \\
32 & $-4.35 \%{ }^{\text {a C }}$ & $-4.78 \%{ }^{\text {a B }}$ & $-5.15 \%{ }^{\text {a B }}$ & $-4.94 \%{ }^{\text {a B }}$ \\
\hline
\end{tabular}

TABLE 4 - Data of the weight loss of fruits fall on rigid surface (equal lower case letters means no significance at $10 \%$ level along the rows, equal upper case letters means no significance at $10 \%$ level along the columns). 


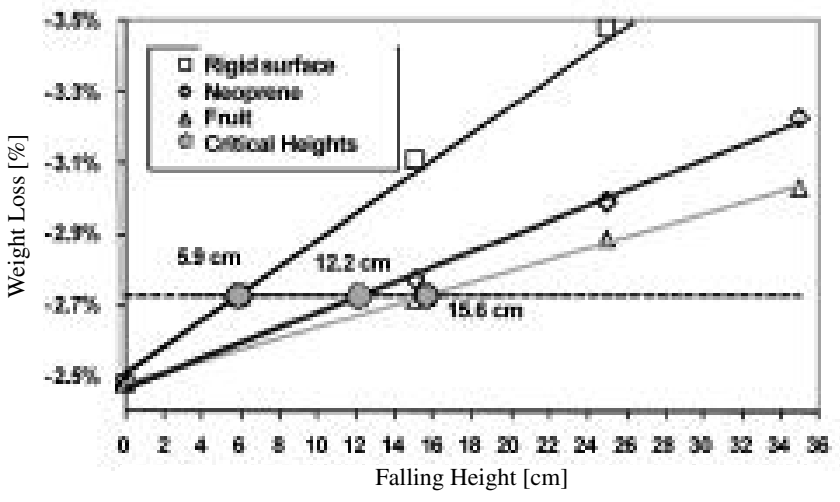

Fig. 4 - Critical damage points calculation for citrus falling on several stuffs (sampled after 13 days of cold storage): a linear relation exists between weight loss and falling height $\left(R^{2}>=0.996\right.$ and p-value $<$ 0.003 ) in the first period of storage.

The results bring an overall significance level below or equal to $10 \%$ only for the sampling after 13 days of cold storage (as reported in tab. 2, tab. 3 and tab. 4) for each tested stuff; the other data don't have so strong statistical evidence. For this reason the 13 days storage sampling time has been used to design the model of the critical damage curve.

In order to evaluate the damage critical curve firstly a threshold value for the weight loss was fixed, equal to the $10 \%$ of the value of the control weight loss: thus weight loss values bigger than the threshold one must be considered unacceptable, and the fruit damaged; therefore, once fixed the sampling time (in this case the first sampling occurred after 13 days), the critical falling height were calculated from the experimental data (overall significance level below or equal to $10 \%$ ), equal to $5.9,12.2$ e $15.6 \mathrm{~cm}$, respectively for rigid surface, neoprene surface and fruit layer, as shown in figure 4; to this aim a linear dependence of the weight loss versus the falling height is supposed to occur in the first sampling period of 13 days, this working hypothesis was confirmed by the linear relation existing between the experimental data as shown in fig. 4 (a statistical analysis of linear dependence brings a $\mathrm{p}$-value $<0.003$ and $\mathrm{R}^{2}>=0.996$ ), furthermore the weight loss is dependent also from the impacted material; in the subsequently sampling periods the linear relation between data is very weak due to other effects that affect the fruits' weight loss. Moreover a linear relation was used (as shown in fig. 4) between the weight loss and the falling height also because the "logistic regression" between impact energy and probability of damage is nearly linear at lower impact energy [Bollen 2001; Desmet 2004; Schulte 1991; Van Linden 2006].

Because the weight loss increase of the control was used as an index of the fruit damage and stated that as threshold value for the weight loss was fixed to the $10 \%$ of the value of the control weight loss, this means that a weight loss lesser than $2.73 \%$ in comparison with the control fruits $(2.48 \%)$ has to be considered as an acceptable damage with a probability of $90 \%$.

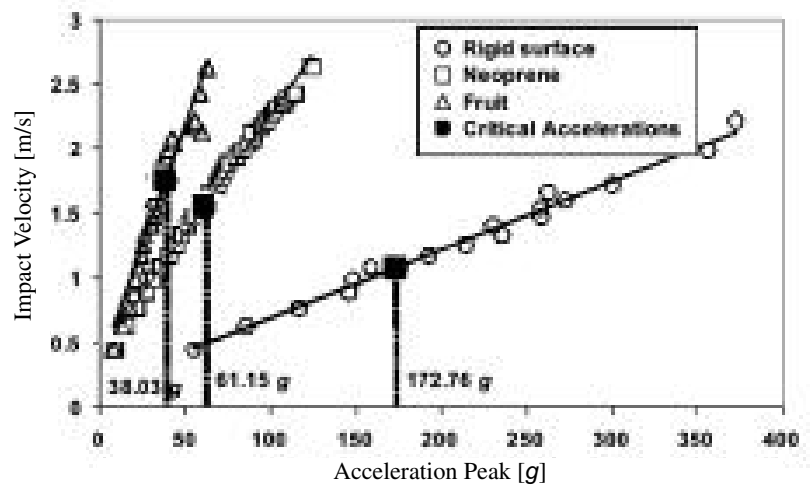

Fig. 5 - Critical points placed on the impact velocity vs. acceleration curves allow the calculation of the maximum acceleration critical peaks, for each stuff.

Then the calculated critical heights were used to determine the critical impact velocities, as $\sqrt{2 \mathrm{gh}}$; these values provide the effect of the impact (for the same height and the same stuff) on the instrumented sphere. The calculated critical points are shown in figure 5, for each tested stuff; these points allow the research of the critical acceleration peaks as measured from the IS100 device in the same energetic conditions.

Entering the values of the critical acceleration peaks as obtained from fig. 5 into fig. 3(b) we obtain the three critical "velocity change" points, equal to $1.69 \mathrm{~m} / \mathrm{s}$, $2.86 \mathrm{~m} / \mathrm{s}$ and $1.90 \mathrm{~m} / \mathrm{s}$, respectively for rigid surface, neoprene surface and fruit layer; then entering the values of these three critical points (velocity change, acceleration peak) into the IS100 software we allow to the IS100 internal software the detection of the critical damage curve for orange fruits (Navelina cv.).

Furthermore by the interpolation of the previous three critical points with a suitable function of power law type we obtain the critical damage curve equation for orange fruits (Navelina cv.):

\section{Velocity Change $=3.9793(\text { Acceleration Peak })^{-0.1489}$}

This critical damage curve allows the evaluation of the damage points along the sorting and packaging line, in oranges processing, using the IS100 device. The found critical points and the related damage curve equation are in good agreement with the expected storage life of the product when the damage impacts are kept below the critical damage curve threshold values.

\section{Results from the tests on the sorting and packaging lines}

The IS100 device allows the evaluation of both the collisions number (collision frequency) and intensity due to the sorting-packing line. This is a fundamental knowledge to compare the several sorting-packing so- 
lutions, with the aim to reduce or eliminate fruits damage and to improve the overall quality.

Generally data show that there is not a specific operation more injurious than others, except the packaging using bags-filler. Even if old, processing lines don't damage the oranges as long as they are both well assembled and well maintained (see fig. 6, fig. 7).

Figure 8 shows that bags filler, and particularly the fruit discharge step of the packaging represent the critical operations for fruit damage.

Particularly it could be considered that:

- sorting system doesn't work out any influence on the fruit, in fact both mechanical (figure 6) and volumetric (figure 7) sorting don't produce any stress as data demonstrate; even though the mechanical sorting system leads to the falling of the fruits on the lower conveyor belt, proper systems (for example blankets or curtains) could be used to reduce the impact;

- the presence of bins filler produces an essential difference among the lines, because increases collisions, both for number and intensity;

- bag-filler produces both high number and intensity collisions, particularly, the chamber emptying system (based on the weight control) and the conveyor duct, which carries the citrus fruits to the package seem careless about the fruit quality preservation. Data show that, both for bags and mesh filling, machines cause an excessive hit for fruits, especially for height more than $60 \mathrm{~cm}$;

- often hits exceed the damage threshold because of a wrong line assembly of the machines constituting the sorting-packing line, this can be observed, for
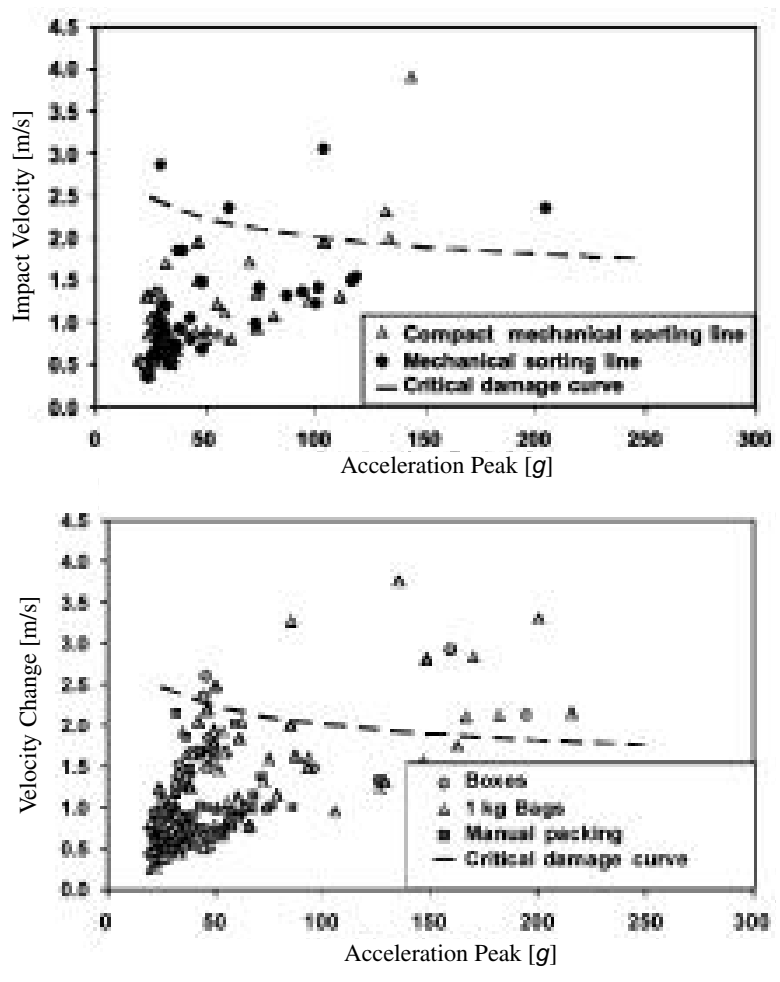

(a)

Fig. 6 - Impacts evaluation on a packing line: mechanical sorting (a) and compact mechanical sorting (b). example, when fruits like peaches or tomatoes are sorted modifying lines originally designed for citrus.

Table 5 shows that discharge step for filling the bag is the most dangerous operation for fruits. In fact, for example, for packaging step, the instrumented sphere recorded values higher than the critical threshold, while sorting-section results more gentle.

So electronic (optic volumetric) sorting systems are suitable for processing several kinds of fruits, like peaches, while mechanical sorting systems need some introduced changes to avoid damages and they cannot be used for all kinds of fruit (see tab. 5).

The assumption that values of the weight loss above the $10 \%$ threshold of the control sample lead fruits to damage has resulted acceptable considering the trials carried out on industrial packing plants.

\section{Simple improvements for orange packing lines}

To evaluate the feasibility of reducing the oranges damages for both sorting and packaging, simple modifies were planned and carried out, using neoprene layers on the steel surfaces mainly involved in causing the fruits hits.

Especially packaging machine was modified, comprising its fruit discharge system; $7 \mathrm{~mm}$ neoprene layers $\left(36.9 \mathrm{~kg} / \mathrm{m}^{3}\right.$ density) were used to cover the entire surface responsible for fruits hit (see fig.8). Moreover the filling duct was covered using neoprene layers and supplied with neoprene fins, to reduce the fruits velocity falling downward.
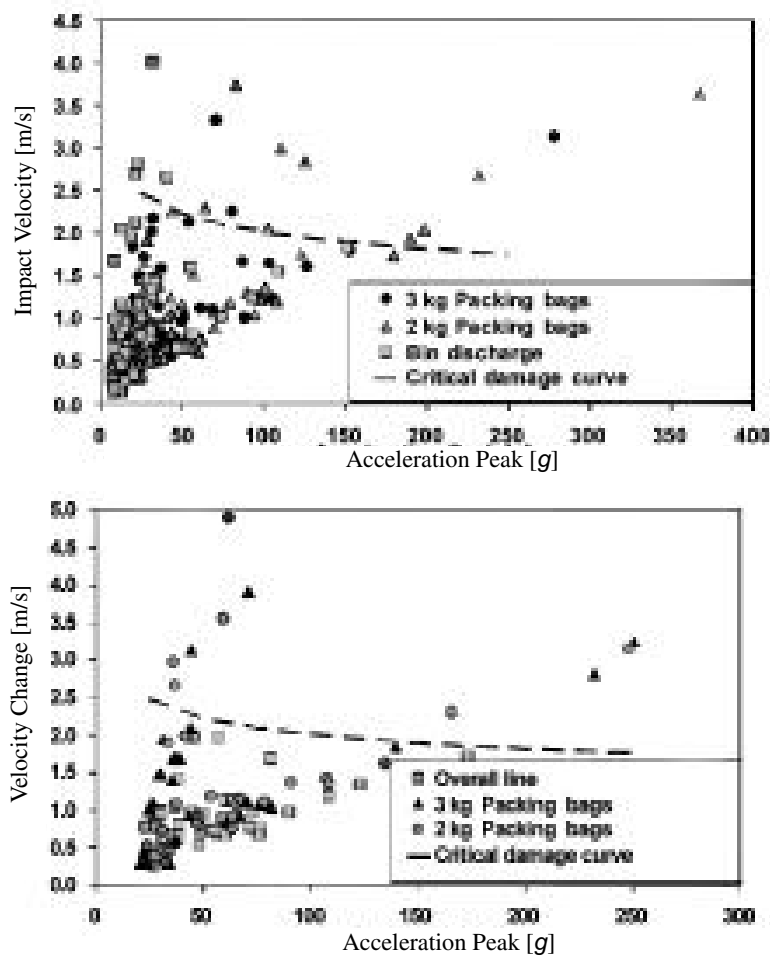

(a)

Fig. 7 - Impacts evaluation on a sorting system supplied packing line: weight based (a) and optic-volumetric (b). 


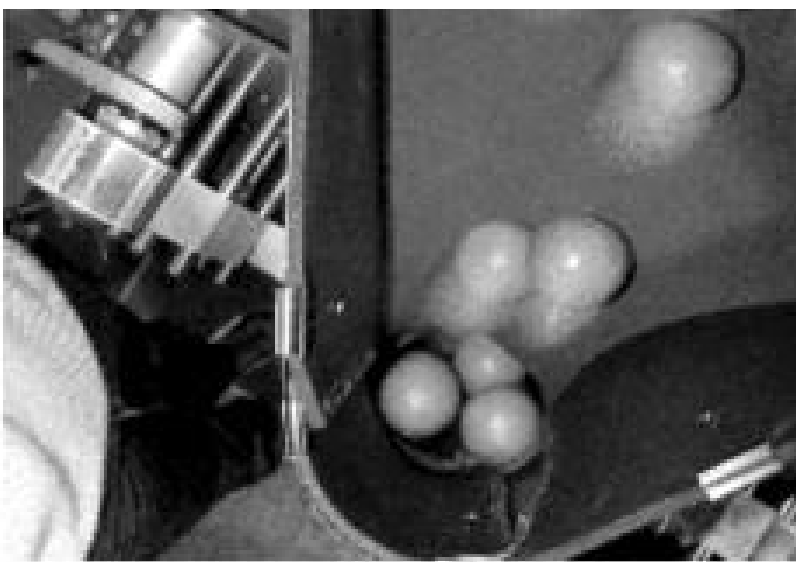

Fig. 8 - Oranges discharge detail, after being covered with neoprene layers ( $7 \mathrm{~mm}$ thick).

Preliminary tests were carried out to evaluate the efficiency of the suggested solution and to optimize it, particularly for the number of fins and their inclination, using a $7 \mathrm{~mm}$ thick neoprene layer, the instrumented sphere ( 1 meter falling height) and the discharge duct (with and without the neoprene fins).

Figure 9 shows that for 1 meter falling height and with three neoprene fins (staggered $45^{\circ}$ angle disposition) a velocity decrease within the threshold value to reduce impact damages was observed.

Figure 10 shows the obtained data for reproducing the laboratory scale modifies on the packaging machine during fruit processing; it underlines that in the presence of the neoprene fins it's possible to eliminate the dangerous collisions without any decrease in the process productivity.

\section{Conclusions}

In this paper a calibration curve for the evaluation of mechanical damage on orange fruits was evaluated, comparing different packing lines and using the IS100 instrumented sphere as testing fruit. Results allow the opportunity to evaluate mechanical damage of orange fruits during sorting - packaging operation. The critical damage curve defined the incidence of the damages during the orange fruits processing and packaging, due to both the collisions frequency and intensity.

Preliminary laboratory tests were made to evaluate (the actual) fruits damages due to specific sorting conditions (fruit falling on both hard surfaces and/or other fruits). Measured values about the falling damage tests on various kinds of materials show a direct correlation between the calculated velocity and the acceleration, except for the impact of IS100 device on the similar fruits, due to the difficulty to carefully hit the target fruit and to inelastic behavior of fruits at the high impact velocities.

A variance analysis (Two-way ANOVA) for the weight loss was performed and a significant variation at a $5 \%$ significance level was found (at a $1 \%$ significance level a significant variation was shown only for falls onto the rigid surface). As expected, the weight loss increased as both the impact energy and the impact surface rigidity increased at sampling after 13 days of cold storage with an overall significance level below or equal to $10 \%$.

Afterwards the instrumentation was tested on the orange processing line, inside a fruit and vegetable processing store.

Data show that the fruit discharge (bins or boxes discharge) and the packaging step are the most critical operations in order to reduce or eliminate the fruits collisions and the consequent damages.

Tests demonstrate that using neoprene layers or fins (minimal neoprene density of $30 \mathrm{~kg} / \mathrm{m}^{3}$ ) to cover the steel surfaces on the processing line, allows to completely eliminate the dangerous collisions, without any decrease in the process productivity.

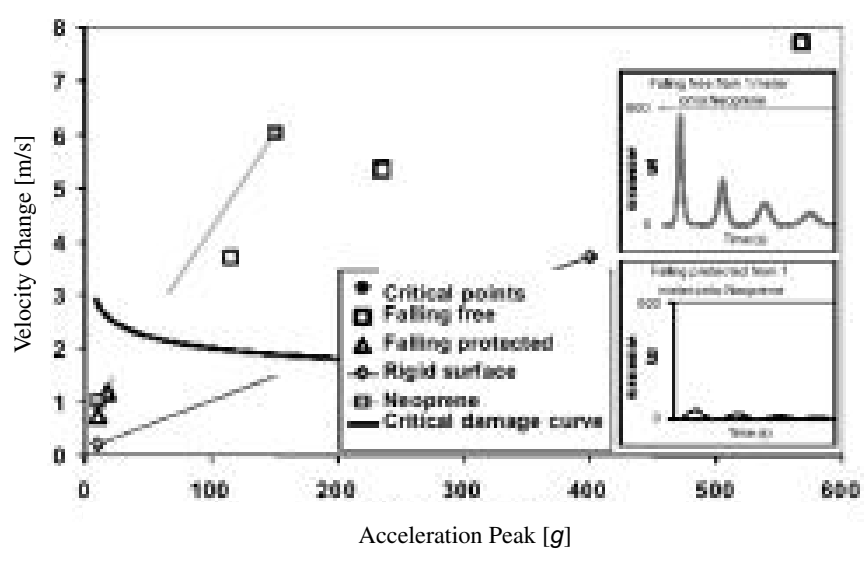

Fig. 9 - Orange fruits impacts evaluation in the presence of the adopted preservation system during pipe discharge packing.

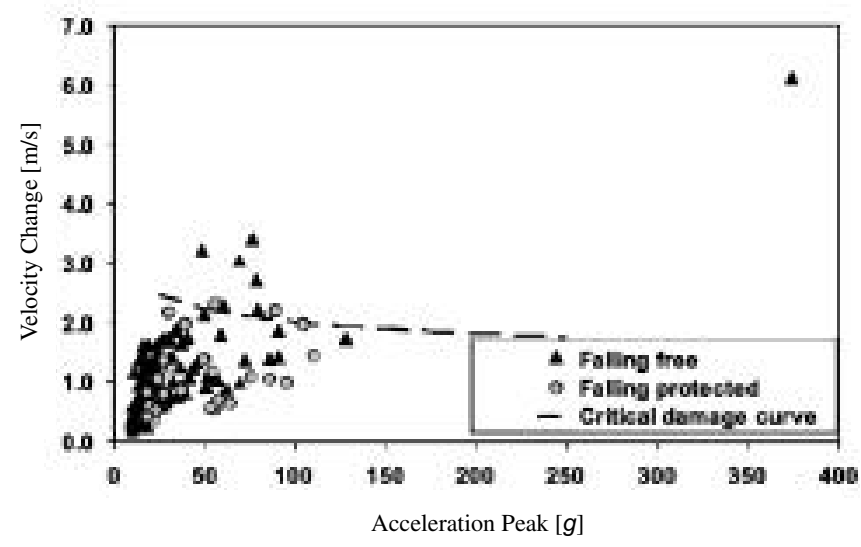

Fig. 10 - Impacts evaluation for packing line tests, with or without adopting fruits preservation system. 


\begin{tabular}{|c|c|c|c|c|c|c|c|c|c|c|c|}
\hline \multirow[t]{2}{*}{ Operation } & \multicolumn{2}{|c|}{ Compact line } & \multicolumn{3}{|c|}{ Mechanical sorting line } & \multicolumn{3}{|c|}{$\begin{array}{c}\text { Optical-volumetric } \\
\text { system }\end{array}$} & \multicolumn{3}{|c|}{ Packaging system } \\
\hline & $\begin{array}{c}\text { With } \\
\text { end-line } \\
\text { packaging }\end{array}$ & $\begin{array}{c}\text { Without } \\
\text { end-line } \\
\text { packaging }\end{array}$ & $\begin{array}{c}\text { Box } \\
\text { discharge }\end{array}$ & Packaging & $\begin{array}{c}\text { Bin } \\
\text { discharge }\end{array}$ & & & & $\begin{array}{l}\text { String } \\
\text { bags }\end{array}$ & Stack & Envelope \\
\hline Bin/Box discharging & & & $\begin{array}{c}76.6 \\
(3.10) \\
167.5 \\
(2.03)\end{array}$ & $\begin{array}{c}86.6 \\
(2.77) \\
87.1 \\
(2.29)\end{array}$ & $\begin{array}{c}112 \\
(3.68) \\
91.5 \\
(3.17) \\
209.3 \\
(2.64) \\
55.5 \\
(2.57) \\
130.7 \\
(2.16)\end{array}$ & & & $\begin{array}{c}85.3 \\
(2.00)\end{array}$ & $\begin{array}{c}76 \\
(3.40) \\
79.2 \\
(2.21)\end{array}$ & . & $\begin{array}{l}367.1 \\
(3.63) \\
231.9 \\
(2.67) \\
198.3 \\
(2.04)\end{array}$ \\
\hline First dumping & $*$ & * & & & $\begin{array}{c}43.6 \\
(3.39)\end{array}$ & & & & $*$ & $*$ & * \\
\hline First sorting & $*$ & $*$ & & & & & & $*$ & $*$ & $*$ & * \\
\hline First conveyor belt & $\begin{array}{l}166.6 \\
(2.11) \\
\end{array}$ & $\begin{array}{l}215.6 \\
(2.14) \\
\end{array}$ & & & & & & & & & \\
\hline \multicolumn{12}{|l|}{ Second conveyor belt } \\
\hline Fruit Raising & & & & & & \begin{tabular}{|c|}
71.2 \\
$(3.90)$ \\
\end{tabular} & & $\begin{array}{c}143 \\
(3.91) \\
131.6 \\
(2.32) \\
\end{array}$ & & & \\
\hline \multicolumn{12}{|l|}{ Washing } \\
\hline Fruit Raising & & & $\begin{array}{c}88 \\
(2.28)\end{array}$ & & & & & & & & \\
\hline Brushing & & & & $\begin{array}{c}32.5 \\
(1.89) \\
\end{array}$ & & & & & & & \\
\hline \multicolumn{12}{|l|}{ Preliminary Drying } \\
\hline Waxing & & & $\begin{array}{c}41.4 \\
(2.40) \\
\end{array}$ & & & & & & & & \\
\hline Drying & & & & $\begin{array}{c}37.4 \\
(0.91) \\
\end{array}$ & & & & & & & \\
\hline Sorting & & & $\begin{array}{c}62.8 \\
(2.22) \\
73.5 \\
(2.17)\end{array}$ & $\begin{array}{c}37.9 \\
(2.37) \\
51.6 \\
(2.77)\end{array}$ & & & & & & & \\
\hline Fruit raising & & & & $\begin{array}{c}67.1 \\
(2.19)\end{array}$ & & & & & & & \\
\hline Sorting line conveyor & & & & & & $\begin{array}{c}49.7 \\
(2.40)\end{array}$ & & & & & \\
\hline \multicolumn{12}{|l|}{ Grading } \\
\hline Singling & $*$ & $*$ & * & * & $*$ & * & * & $*$ & $\begin{array}{c}48 \\
(3.20) \\
68.8 \\
(3.04) \\
60.7 \\
(2.29)\end{array}$ & & $\begin{array}{c}82.7 \\
(3.74) \\
110.2 \\
(3.00) \\
125.3 \\
(2.83) \\
63.9 \\
(2.29) \\
102.1 \\
(2.05) \\
189.7 \\
(1.93)\end{array}$ \\
\hline $\begin{array}{l}\text { Packaging line } \\
\text { feeding }\end{array}$ & $\begin{array}{c}182 \\
(2.13)\end{array}$ & $\begin{array}{c}85.6 \\
(3.27)\end{array}$ & & & & & & & & & \\
\hline
\end{tabular}




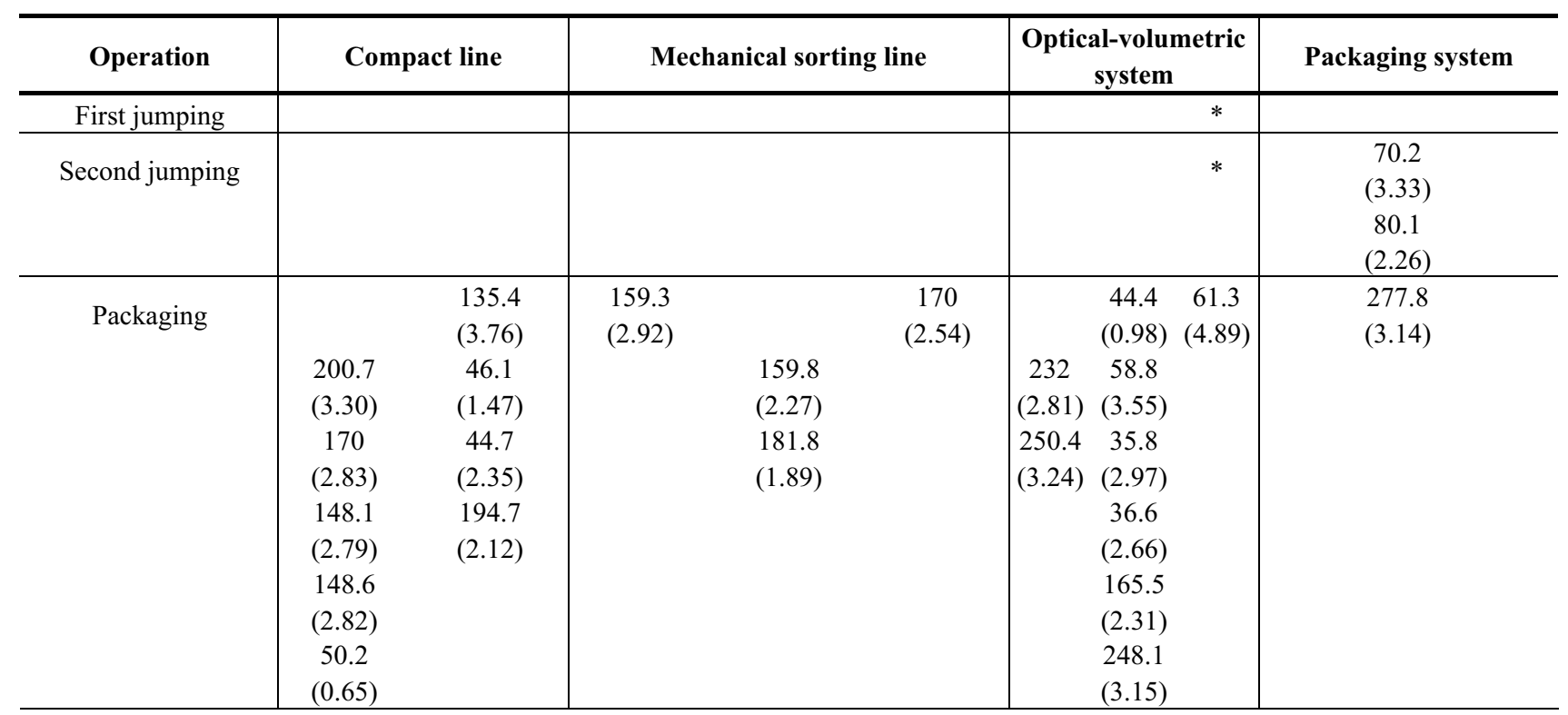

TABLE 5 - Measured IS100 device acceleration peaks $(g)$ and "velocity change" $(\mathrm{m} / \mathrm{s})$, in parenthesis, during oranges sorting packaging operations.

\section{References}

Alferez F., Agusti M., Zacarias L. Postharvest rind staining in Navel oranges is aggravated by changes in storage relative humidity: effect on respiration, ethylene production and water potential. Postharvest Biology and Technology (2003), (28): 143-152.

Bajema R.W., Hyde G.M. Instrumented pendulum for impact characterization of whole fruit and vegetable specimens. American Society of Agricultural Engineers (1998), (41): 1399-1450.

Bajema R.W., Hyde G.M., Peterson K. Instrumentation design for dynamic axial compression of cylindrical tissue samples. American Society of Agricultural Engineers (1998), (41): 747-754.

Baritelle A., Hyde G. Commodity conditioning to reduce impact bruising. Postharvest Biology and Technology (2001), (21): 331-339.

Beni C., Iannicelli V., Di Dio C. Il condizionamento dei prodotti ortofrutticoli. [The conditioning of fresh fruits and vegetables] (in italian). (2001), Edagricole.

Blandini G., Cerruto E., Manetto G. Danni da urto ripetuto nelle linee di lavorazione degli agrumi: caratterizzazione del fenomeno e conseguenti indirizzi costruttivi delle macchine. [Injuries by repeated impacts onto packing house working lines: characterization of the phenomenon and guidelines for working lines building] (in italian). Convegno su "Linee programmatiche di indirizzo e intervento per l'agrumicoltura italiana" - Acireale (CT), (2007), 30 maggio - 1 giugno.

Blandini G., Caruso L., Cerruto E., Manetto G., Romano E. Il danneggiamento delle arance nel post-raccolta: l'effetto degli urti. [The oranges damage during postharvest: the effect of impacts] (in italian). Atti del VIII Convegno Nazionale di Ingegneria Agraria. Catania, (2005), 27-30 giugno.

Blandini G., Cerruto E., Manetto G., Romano E. Mechanical damage to oranges caused by repeated impact against steel. Atti del XXX CIOSTA - CIGR V Congress - Management and Technology Applications to Empower Agriculture and Agro-food Systems. Grugliasco (TO), (2003), 22-24 settembre: 400-407.

Bollen A.F., Timm E.J., De La Rue B.T. Relation of individual forces on apples and bruising during orchard transport of bulk bins. Appl. Eng. Agric. (2001): 193200.

Bollen A.F., De La Rue B.T. Impact analysis using video with instrumented sphere. American Society of Agricultural Engineers Paper (1990), (90): 6078. ASAE Summer Meeting, Columbus, OH.

Bollen A.F., Cox N.R., Dela Rue B.T., Painter D.J. A descriptor for damage susceptibility of a population of produce. Journal of agricultural Engineering Researches (2001), 78(4): 391-395.

Brown G.E., Eckert J.W. Green Mold, Compendium of Citrus Diseases - American phytopathological Society Press, L.W. Timmer, S.M. Garnsey, J.H. Graham (Editors), (2000): 41-42.

Cerruto E., Manetto G., Romano E. Danneggiamento delle arance nel post-raccolta. [Oranges damage during postharvest] (in italian). Italus Hortus (2004), (11): 72-75.

Crisosto C.H., Slaughter D., Garner D., Boyd J. Stone fruit critical bruising thresholds. Journal American Pomological Society (2001), 55(2): 76-81.

Delwiche M. J., Arevalo H., Mehlschau J. Second generation impact force response fruit firmness sorter. American Society of Agricultural Engineers (1996), (39): 1025-1033.

Desmet M., Van linden V., Hertog M.L.A.T.M., Verlinden B.E., De Baerdemaeker J., Nicolai B.M. Instrumented sphere prediction of tomato stem-puncture injury. Postharvest Biology and Technology (2004), 34: 81-92.

Di Renzo G.C., Altieri G. Attrezzatura per il monitoraggio delle sollecitazioni meccaniche subite dai frutti durante le operazioni post-raccolta. [A device to monitor the mechanical stresses suffered by fruits during postharvest 
handling practices] (in italian). Italus Hortus (1997), (4): 67-70.

Gan Mor S., Galili N. Rheological model of fruit collision with an elastic plate. Journal Agricultural Eng. Res. (2000), (75): 139-147.

Garcia J.L., Ruiz-Altisent M., Barreiro P. Factors Influencing Mechanical Properties and Bruise Susceptibility of Apples and Pears. Journal of Agricultural and Engineering Research (1995), (61): 11-18.

García Ramos, F.J., Ortiz-Cañavate, J., Ruiz-Altisent, M. Evaluation and correction of the mechanical aggressiveness of commercial sizers used in stone fruit packing lines. Journal of Food Engineering (2004), (63): 171176

Garcìa Ramos F.J., Ortiz Cañavate J., Ruiz-Altisent M. Decelerator elements for ramp transfer points in fruit packing lines. Journal of Food Engineering (2003), (59): 331-337.

Henriod R.E. Postharvest characteristics of navel oranges following high humidity and low temperature storage and transport. Postharvest Biology and Technology (2006), (42): 57-64.

Laykin S., Edan Y., Alchanatis V., Development of a quality sorting machine using machine vision and impact. ASAE (1999), (99): 3144.

MATLAB Statistic Toolbox Reference, (2001), The MathWorks Inc.

Mohammed M., Brathwaite R.A.I. Ripening effects on the chilling sensitivity of processing and non-processing tomato cultivars. Journal of Appl. Hort. (2000), (2): 7678.

McGlone V.A., Jordan R.P., Schaare P.M. Obtaining mass from fruit impact response. American Society of Agricultural Engineers (1997b), (40): 1417-1419.

Miller W.M., Wagner C.J. Florida citrus packing line studies with an instrumented sphere. Applied Engineering in Agriculture (1991), (7): 577-581.

Mohsenin N.N., Physical properties of plant and animal materials. Gordon and Breach Science Publishers, Second Updated and Revised Edition (1986).

Opara L.U. Bruise susceptibilities of 'Gala' apples as affected by orchard management practices and harvest date. Postharvest Biology and Technology (2007): 47-54.

Ragni L., Colorio G., Vassalini G. Risposta dinamica di uno strumento per la misura degli impatti subiti dai frutti nelle linee di lavorazione post-raccolta. [Dynamical response of an instrument for the measure of impacts suffered by fruits onto postharvest working lines.] (in italian). Rivista di Ingegneria Agraria (1998), (1): 16-25.

Schulte N., Timm E., Ladd J., Brown G., Peach and pear impact damage thresholds: a progress report. Paper No. 916620. ASAE Winter Meeting (1991), Chicago, IL, USA.

Snedecor G.W., Coochran W.G., Statistical Methods. 8th Edition (1989), Iowa State University Press, Ames, Iowa 50010.

Skaria M., Eayre C.G., Miao H., Solis Gracia N., Mackey B. Effect of Packing on Rot and fruit Damage in Rio Red Grapefruit. Subtropical Plant Science (2003), (55): 75-78.

Tennes B.R., Zapp H.R., Brown G.K., Ehlert S.H., SelfContained Impact Detection Device: Sorting and Accuracy. American Society of Agricultural Engineers (1988), (31): 1869-1834.

Van linden V., De Ketelaere B., Desmet M., De Baerdemaeker J., Determination of bruise susceptibility of tomato fruit by means of an instrumented pendulum. Postharvest Biology and Technology (2006), 40: 7-14.

Zapp H.R., Ehlert S.H., Brown G.K., Armstrong P.R., Sober S.S., Advanced instrumented sphere (IS) for impact measurements. American Society of Agricultural Engineers (1990), (33): 955-960.

Zerbini P.E. 2003. Tecnologie innovative post-raccolta per preservare e migliorare la qualità della frutta. Frutticoltura (2003), (5): 51-54.

\section{SUMMARY}

Oranges quality is strictly dependent on their variety, pre-harvest and post-harvest practices. Especially post harvest management is responsible for fruits damages, causing quality deterioration and commercial losses, as underlined by many authors, which studied the influence of individual post harvest operations on the fruit quality. In this article Authors, using an instrumented sphere (IS 100) similar for shape and size to a true orange, showed a method for the control of orange damages along the processing line. Results allow a fundamental knowledge about the critical damage curve, which defines the incidence of the damages during the oranges processing and packaging. Data show that the fruit discharge (bins or boxes discharge) and the packaging step are the most critical operations in order to reduce or eliminate the fruits collisions and the consequent damages.

Keywords: orange, instrumented sphere, IS100, mechanical damage, handling, packing. 
